\title{
The Fifth Skill in Language Learning: Culture
}

\author{
Mustafa Altun ${ }^{1}$ \\ ${ }^{1}$ English Language Teaching Department, Tishk International University, Erbil, Iraq \\ Correspondence: Tishk International University, Erbil, Iraq \\ Email: mustafa.altun@ishik.edu.iq
}

Received: April 5, 2019

Accepted: May 18, 2019

Online Published: June 1, 2019

doi: 10.23918/ijsses.v5i4p162

\begin{abstract}
Language teaching generally puts the emphasis on the development of four basic skills; listening, speaking, reading and writing. With this in mind, teaching culture was neglected in the language classroom. However, with the advent of communicative language teaching in the late 1970s the interrelatedness of language and culture became clear and language teachers experienced a swing against including culture in language teaching. Language and culture are inseparable and mutually reinforcing; in addition, without fully understanding culture, it is hard to acquire a language. Linguistic proficiency alone does not help language learners develop intercultural communication. This paper aims to explore the relationship between culture and language and attempts to show why culture holds an important place in language learning.
\end{abstract}

\section{Keywords: Language, Culture, Interrelatedness, Communicative Language}

\section{Introduction}

Learning a language includes also the study of its culture; however, the role of culture in language learning has always been debated. Although a large number of recent studies focused on the pivotal role of culture in language learning (Kramsch, 2001; Byram, 1997; Kramsch, Cain \& Murphy-Lejeune, 1996; Byram \& Morgan, 1994) the relationship between them has always been a challenging issue for language teachers and educators. With the advent of communicative language teaching in the late 1970s language teachers experienced a swing against including culture in language teaching (Pulverness, 2003), and since then culture has made a place for itself in language learning. Many researchers agree with the premise that learning culture is in tandem with language learning. Ellis (1985) argues that language is one of "the most observable expressions of culture" (p. 251). Brown (2007) explains the interrelatedness of language and culture as "Language is a part of a culture, and culture is a part of the language; the two are intricately interwoven so that one cannot separate the two without losing the significance of either language or culture" (pp. 189-190). Kuang (2007) postulated the synonymy between language and culture and maintains that "Language is the carrier of culture and culture is the content of language" (p. 75). Language learning without knowing its culture is a hard issue. Kuang (2007) states that language learning and learning its culture is inseparable. Similarly, Damen (1987) notes that "language learning implies and embraces culture learning" (p.4). Seliger (1988) sets forth the 
reasons why culture impacts on language learning and posits that in social exchanges language is used and culture influences the way people respond each other.

According to the National Standards for Foreign Language Learning (1996), culture includes three components: perspectives, products and practices.

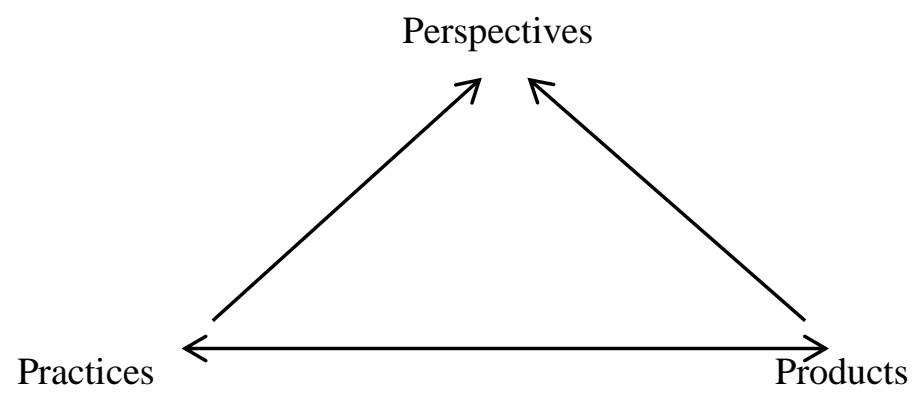

Figure 1: Three components of culture (The National Standards in Foreign Language Education Project, 1996, p.43)

Cultural perspectives refers to values, beliefs, ideas and attitudes L2 culture members have; cultural products can be either tangible (literature, books, paintings) or intangible (education system, music) and cultural practices are patterns of social interactions. These three components transcend human life entirely. Culture is incorporated in all spheres of human life.

\section{Literature Review}

Language curriculum has three components: language, literature and culture (Lafayette, 1988). A great deal of time is devoted to the grammatical and lexical aspects of language and culture is getting less attention "due to its uneven treatment in textbooks and to the lack of familiarity, among teachers, with the culture itself and with the techniques needed to teach it" (p. 47). However, culture should be perceived to be a part of language learning. Likewise, Byram (1997a) suggests three goals of foreign language teaching:

a) The development of communicative competence

b) The development of language awareness

c) The development of cultural awareness

It is clearly seen that culture is one of the major goals of language learning and it is convenient to say that culture is central to language learning. A well-known definition of culture comes from Goodenough (1957) "... a society"s culture consists of whatever it is one has to know or believe in order to operate in a manner acceptable to its members, and to do so in any role that they accept for any one of themselves (p. 167). Kramsch (1993) defined culture as "membership in a discourse community that shares a common system of standards for perceiving, believing, evaluating and action" (p. 127). Based on these definitions, it is possible to say that language and culture are related and without culture language learning is incomplete. Advocating this idea Damen (1987) argues that culture is a great part of language 
and cultural patterns are applied in language. Similarly, Kramsch (1993) describes the bond between language and culture as "Language is the principal means whereby we conduct our social lives. When it is used in contexts of communication, it is bound up with culture in multiple and complex ways "(p.3). In a cultural context in order to communicate within a social group in addition to knowledge and language knowledge about values and beliefs is required. The lack of exposure to cultural elements of a society can hinder communication. Bada (2000) makes it clear that cultural knowledge is a need for people to establish good communication and states that "the need for cultural literacy in ELT arises mainly from the fact that most language learners, not exposed to cultural elements of the society in question, seem to encounter significant hardship in communicating meaning to native speakers" (p. 101). Addressing people, making requests, asking for permission, expressing gratitude, agreeing or disagreeing with someone require learners to be aware of cultural norms. Hence, language learning does not take place without cultural awareness (Peterson \& Coltrane, 2003).

Communicative competence is functioning in an appropriate way in a communicative setting. In other words, it is "a term which alludes to tacit knowledge of language and the ability to understand and use the language effectively for communication purposes" (Mart, 2017, p.163). The communicative competence model developed by Canale and swain (1980) had four components: linguistic competence (knowledge about the system of language), sociolinguistic competence (appropriate use of language in social contexts), discourse competence (connection of language structures for a meaningful discourse), strategic competence (communication strategies for efficiency). Bardos (2004) added culture to the model developed by Canale and Swain as a fifth competence. He argues that culture is a part of all other competences.

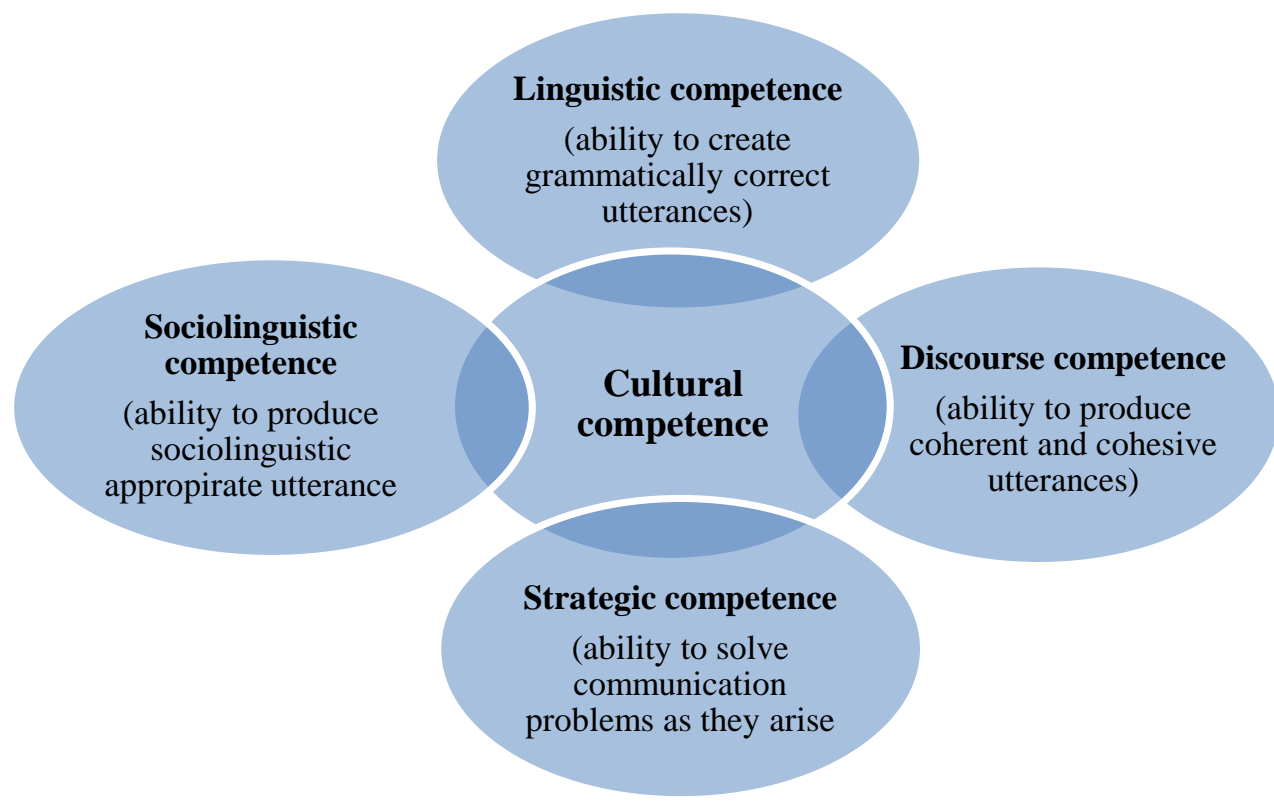

Figure 1: Cultural competence in communicative competence (Bardos, 2004, p.151) 
Paige et al. (2003) stresses the importance of culture learning in second language learning and points out that "the process of acquiring the culture-specific and culture-general knowledge, skills, and attitudes required for effective communication and interaction with individuals from other cultures. It is a dynamic, developmental, and ongoing process which engages the learner cognitively, behaviorally, and affectively (p.177). To become competent for communication in the target language, learners need to learn the traditions and customs of the speech community.

Klink (1980) points out that "research on second language learning suggests that learners learn better in contact with the target language and culture. Classroom experiences alone cannot fulfill this need" (p. 4). Teaching culture cannot be ignored in language teaching. Confirming this notion Seelye (1993) asserts that "learning a language in isolation of its cultural roots prevents one from becoming socialized into its contextual use. Knowledge of linguistic structure alone does not carry with it any special insight into the political, social, religious, or economic system. Or even insight into when you should talk and when you should not" (p. 10). The study of culture renders the study of language meaningful (Stainer, 1971). Without background knowledge for the examples provided while teaching, learning will be fictive. The provision of cultural aspects of a language enables learners to relate language elements to people and places of the language where it is spoken. We cannot deny that motivation has a primary role in language learning. The study of culture benefits language learners to a large extent by virtue of the fact that leaners' curiosity and interest in target countries and their people is increased.

The use of authentic materials in language teaching offers cultural experiences to learners. These authentic materials such as newspapers, travel brochures, websites, television shows, etc. allow learners to obtain behaviors including eye contact, the use of body language, the distance between people as they interact and try out these strategies during communication in the target language. For instance, Valdes (1986) convincingly argues that literature is a useful source to help learners have greater insight into the target language culture. Lafeyette (1988) suggests the integration of culture and language activities such as vocabulary and grammar exercises to teach culture to learners in the language classroom. Peterson and Coltrane (2003) presented some instructional strategies to employ for teaching cultural aspects:

a) Using authentic materials; literature, films, newspapers, magazines, etc.

b) Teaching proverbs

c) Using learners from other cultures in the classroom and allow them to present their own culture

d) Asking learners to collect information about the target language culture

e) Presenting objects originates from the culture of the target language and asking learners to do a research on them

Learning is conducted in an unreal situation in the classroom; for that reason, including culture in classroom instruction help learners engage in real world experiences. Learning culture allows learners to practice better and facilitates learning. Moreover, cultural instruction motivates them towards language learning.

\section{Conclusion}

The review of literature in this study makes it clear that language and culture coexist in any society and they are interconnected. In order learners to master the target language, they should simultaneously 
focus on language and culture. To communicative effectively in the target language learners need both linguistic and cultural competence as linguistic proficiency alone does not meet the needs of language learners for successful intercultural communication. Therefore, more noticeable efforts are needed to equip learners with cultural knowledge of the target language.

\section{References}

Bada, E. (2000). Culture in ELT. Cukurova University Journal of Social Sciences, (6), 100-110.

Bárdos, J. (2004). Kulturális kompetencia az idegen nyelvek tanításában [Cultural competence in foreign language teaching]. In: Bárdos, Jenő, Nyelvpedagógiai tanulmányok [Studies in language pedagogy]. Pécs: Iskolakultúra. 142-157. 2005. Élő nyelvtanítás-történet [A living history of language teaching]. Budapest: Nemzeti Tankönyvkiadó.

Brown, H. D. (2007). Principles of language learning and teaching. New York, NY: Pearson Education. Byram, M. (1997a). Teaching and assessing intercultural communicative competence, Chapter 5, Assessment, Clevedon: Multilingual Matters, pp. 87-11.

Byram, M. (1997). Cultural awareness' in vocabulary learning. Language Learning Journal, 16, 51-57.

Byram, M., \& Morgan, C. (1994). Teaching-and-learning language-and-culture. Clevedon: Multilingual Matters Ltd.

Canale, M., \& Swain, M. (1980). Theoretical bases of communicative approaches to second language teaching and testing. Applied Linguistics, 1,1-47.

Damen, L. (1987). Culture learning: The fifth dimension in the language classroom. Reading, MA: Addison-Wesley.

Ellis, R. (1985). Understanding second language acquisition. Oxford: Oxford University Press.

Goodenough, W. H. (1957). Cultural anthropology and linguistics. In P. L. Garvin (Ed.), Report of the seventh round table meeting on linguistics and language study (pp. 167-173). Washington, DC: Georgetown University Press.

Klink, P. (1980). Evaluation of the French immersion weekends. (ERIC Document Reproduction Service NED 201178).

Kramsch, C. (1993). Context and culture in language teaching. Oxford: Oxford University Press.

Kramsch, C. (2001). Language and culture. Oxford: Oxford University Press.

Kramsch, C., Cain, A., \& Murphy-Lejeune, E. (1996). Why should language teachers teach culture? Language, Culture and Curriculum, 9(1), 99-107.

Kuang, J. F. (2007). Developing students' cultural awareness through foreign language teaching. SinoUS English Teaching, 4 (12), 74-81.

Lafayette, R. C. (1988). Integrating the teaching of culture into the foreign language classroom. In A. J. Singerman (Ed.), Toward a new integration of language and culture (pp. 47-62). Middlebury, VT: Northeast Conference on the Teaching of Foreign Languages.

Mart, C.T. (2017). From communicative competence to language development. International Journal of English Linguistics, 8(2), 163-167.

National Standards in Foreign Language Education Project (1996). Standards for foreign language learning in the $21^{\text {st }}$ century. Lawrence, KS: Allen Press.

Paige, R. M., Jorstad, H. L, Siaya, L., Klein, F., \& Colby, J. (2003). Culture learning in language education: A review of the literature. In D. L. Lange \& R. M. Paige (Eds.), Culture as the core: Perspectives on culture in second language learning (pp.173-236). Greenwich, CT: Information Age Publishing.

Peterson, E., \& Coltrane, B. (2003). Culture in second language teaching. CAL Digest, 3(9), 1-6.

Pulverness, A. (2003). Distinctions \& Dichotomies: Culture-free, Culture-bound. Retrieved on June 17, 2004 from http://elt.britcoun.org.pl/forum/distanddich.htm. 
Seelye, H. (1993). Teaching culture: strategies for foreign language educators. 3rd ed. Lincolnwood: National Textbook Company.

Seliger, H. (1988). Psycholinguistic issues in second language acquisition. In L. Beebe (Ed.), Issues in second language acquisition: Multiple perspectives. New York, NY: Newbury House.

Stainer, F. (1971). Culture: A motivating factor in the French classroom. In C. Jay \& P. Castle (Eds.), French language education: The teaching of culture in the classroom. Springfield, IL: State Department of Public Instruction.

Sun, L. (2013). Culture teaching in foreign language teaching. Theory and Practice in Language Studies, 392), 371-375.

Valdes, J. M. (1986). Culture in literature. In J. M. Valdes (Ed.), Culture bound (pp. 137-147). New York, NY: Cambridge University Press. 